\title{
Conducting Multiracial Feminist Family Research: Challenges and Rewards of Recruiting a Diverse Sample ${ }^{1}$
}

\author{
Nancy J. Mezey ${ }^{2}$
}

\begin{abstract}
This paper discusses the importance of conducting feminist family research grounded in multiracial feminism. The author describes how a diverse group of lesbians decided to become mothers or remain childfree and illustrates challenges, overcoming challenges, and rewards in recruiting such a sample. The article discusses selecting a research method, definitions, insider/outsider status, power, and sampling strategies. Despite difficulties, the rich findings make the recruiting effort worthwhile because it expands our understanding of families.
\end{abstract}

Key Words: Sample recruitment, feminist methodology, multiracial feminism, lesbian families, lesbian mothers, mothering decisions

${ }^{1}$ The author wishes to thank Johanna Foster for her comments and suggestions on earlier versions of this paper. The author thanks Maxine Baca Zinn for her help in framing the research and her comments on earlier drafts. Thanks also to Heather Dillaway for her support in conducting focus groups and her comments on this manuscript. This research would not have been possible without the cooperation and input of the women who participated in the study; many thanks to all of them.

${ }^{2}$ Nancy J. Mezey, Ph.D., is Assistant Professor, Sociology Program, Department of Political Science, Monmouth University, West Long Branch, New Jersey 07764. Electronic mail may be sent via the Internet tonmezey@monmouth.edu.

In order to fully understand families, sociologists must place race, class, gender, and sexuality at the center of their research. My graduate training in sociology guided me toward a feminist analysis of the intersections of race, class, and gender - what Baca Zinn and Dill (1996) referred to as "multiracial feminism." Multiracial feminism is a social structural and social constructionist 
approach that "challenge[s] the hegemony of feminisms constructed primarily around the lives of white middle-class women" (Baca Zinn \& Dill, 1996, p. 323). Rather than thinking about women as a cohesive group, multiracial feminism places difference at the center of its analysis to examine how women are dissimilar from one another based on race and class. Just as feminists critique non-feminists for marginalizing women, multiracial feminism critiques earlier feminisms for making invisible and distorting the lives of women of color (Baca Zinn \& Dill, 1996).

Many sociologists agree that theory drives method (Deem, 2002; Harding, 1991; Thompson, 1992). A commitment to multiracial feminism, therefore, suggests that researchers must conduct studies focusing on how people's experiences differ based on their specific race, class, gender, and sexual locations. For this study, I researched the lesbian baby boom (Lewin, 1993; O'Sullivan, 1995; Weston, 1991), focusing on lesbians' decisions to become mothers or remain childfree. The lesbian baby boom has been forming over the past 20 to 30 years. It started with women who became mothers within heterosexual identities and then later identified as lesbians, a group that I refer to as first-generation lesbian mothers. More recently, there has been an increase in second-generation lesbian mothers, that is, lesbians within their identities as lesbians who have been choosing motherhood by adopting, birthing children, and becoming foster parents (Lewin 1993; Silber 1991). At the turn of the millennium, an estimated 22 percent of partnered lesbians had children in their homes (Black, Gates, Sanders, \& Taylor 2000). Furthermore, somewhere between 780,000 and 9 million children live in lesbian and gay families (Stacey \& Biblarz 2001).

While lesbians have been forming families both with and without children over the past 20 to 30 years, they have been doing so within a rocky and often contradictory social and cultural climate. Despite this trend, the few studies conducted on children of lesbian families show that these children are at least as "normal" and "healthy" as children raised in heterosexual families (Stacey \& Biblarz, 2001). Children of lesbians show no more psychotic disorders, anxiety levels, depression, emotional, or behavioral problems than those raised in heterosexual families. Furthermore, children of lesbian parents have the same quality of peer relationships as children of heterosexual parents (Golombok \& Tasker, 1997; Mooney-Somers \& Golombok, 2000; Patterson, 1996; Stacey \& Biblarz, 2001).

Because much of the literature on lesbian families to date has focused on lesbian mothers from White, middle-class backgrounds (Demo \& Allen, 1996; Morningstar, 1999), one of my major research questions was how race, class, 
gender, and sexuality shape lesbians' decision-making processes. Based on these research questions, my study required that I recruit a diverse sample of lesbians.

Although there are existing debates as to whether or not there is a feminist methodology (e.g., Allen, 2004; Baber, 2004; Chafetz, 2004; Gorelick, 1991; Stacey, 1988, Thompson, 1992), I take the position that feminist methodology does exist. In this article, I discuss the importance of conducting feminist family research guided by multiracial feminism and describe the challenges, ways of surmounting those challenges, and rewards of recruiting a diverse sample. My premise is that despite the difficulties of recruiting a diverse sample, the rich findings such a sample produces makes the recruiting effort worthwhile because it expands our understanding of families.

\section{Recruiting a Diverse Sample: Considerations, Challenges, and Solutions}

Feminist researchers have discussed several considerations and challenges in conducting research. For example, they discuss problems in defining terms (Acker, 1999), ethical issues of unequal power relations between researchers and participants (Andersen, 1993; Baca Zinn, 1979; Stacey, 1988; Thompson, 1992), gaining access to minority populations (Andersen, 1993; Baca Zinn, 1979), and problems with accurately interpreting and analyzing participants' responses (Andersen, 1993; hooks, 1989; Riessman, 1991). In designing a feminist research project, conducting my study, and attempting to recruit a diverse sample, I faced similar challenges - as well as challenges concerning how to choose a research method and sampling techniques. What distinguishes my research from previous research on lesbian mothers is that my study was grounded in multiracial feminism, thus creating greater complexity in the study's method.

There are six themes of multiracial feminism that informed this study. First, multiracial feminism conceptualizes race, class, gender, and sexuality as key components in what Patricia Hill Collins called the "matrix of domination" (Baca Zinn \& Dill, 1996). A matrix of domination consists of the multiple, cross-cutting, systems of inequality that affect women and men differently (Collins, 1990). By using the matrix of domination as an analytic tool, multiracial feminism examines how women can simultaneously experience themselves as gendered, raced, classed, and sexualized (Baca Zinn \& Dill, 1996). Second, intersecting hierarchies can both oppress and privilege the same person. For example, a White lesbian can be privileged by her race but oppressed by her gender and sexuality. Third, race, class, gender, and sexuality are relational. Because hierarchical systems are based on power relations, they create 
relationships in which one group's privilege is reliant on another group's oppression. Fourth, multiracial feminism examines the relationship between social structure and women's agency. In my study, I was interested in how lesbians negotiated various social structures in order to make individual mothering decisions. Fifth, multiracial feminism uses wide-ranging methodological approaches, drawing on "three guiding principles of inclusive feminist inquiry: 'building complex analyses, avoiding erasure, and specifying location"” (Frankenberg \& Mani, 1993, as cited in Baca Zinn \& Dill, 1996, p. 328). This theme is particularly relevant to the focus of this article and how I developed and carried out the research methodology for my study. Finally, multiracial feminism integrates "the lived experiences of diverse and continuously changing groups of women" (Baca Zinn \& Dill 1996, p. 328) to understand commonalities and differences among women.

For my study, the themes of multiracial feminism provided the necessary theoretical and analytic tools to question how race, class, gender, and sexuality as interconnected social structures shape the lives of lesbians and their decisionmaking processes. Furthermore, my grounding in multiracial feminism allowed me to draw on the experiences of a diverse group of lesbians to inform the field of family sociology. Drawing on multiracial feminism also meant that the sampling procedure I developed was necessarily complex. Not only was I studying multiple race and class positions, but also differences based on sexuality and mothering decisions (i.e., whether to become a mother or remain childfree). The following discussion focuses on five challenges - created in many ways by my commitment to conducting multiracial feminist research-and on the strategies I used to overcome those challenges.

\section{Selecting a Research Method}

The first methodological consideration in conducting my research involved choosing a method that lent itself to my study. I had to consider how difficult it might be to recruit my ideal sample, the social location of my participants, and the questions I would be asking them. I selected focus groups to provide the main source of data because they were best suited to my study in three major ways. First, focus groups "can thematically identify the diversity of viewpoints or the range of behavior patterns associated with particular issues" (Jarrett, 1993, p. 191) with a small group of people in a relatively short period of time. Given the difficulty I anticipated in recruiting lesbians of diverse race and class backgrounds, employing a research method that maximizes the information generated by a small group of people was ideal.

Michigan Family Review, 10, 45-65, 2005 C Michigan Council on Family Relations 
Second, focus groups allow homogenous groups of people who have historically had limited power and influence to express their opinions together in a non-threatening and comfortable setting (Morgan \& Krueger, 1993). This advantage seemed particularly important when interviewing lesbians of color and working-class lesbians. I wanted to conduct eight focus groups comprised of homogeneous sets of participants, segmented not only by race and class backgrounds but also by mothering decision (i.e., whether the participants were mothers or childfree). Drawing on homogeneous groups of participants allowed me to make comparisons across different groups of lesbians (Knodel, 1993), a main goal of the study.

Finally, I wanted to find a method that would encourage participants to discuss in critical ways a topic that they may not have really thought about prior to participating in the study. Upon starting my research, it was unclear to me how much lesbians think about wanting to have children or remain childfree. For example, a common response Lewin (1993) received from the participants in her study on lesbian mothers was that motherhood was "something they have always wanted," that is, they saw their desire for children as a natural desire. Focus groups were ideal for my study in that they can facilitate conversation and unearth complex explanations about topics that are either habit-ridden or that have not been thought out by the participant prior to being asked (Morgan, 1997; Morgan \& Krueger, 1993). Carefully selecting a suitable research method alleviated some of my concerns about having to recruit a larger sample than might otherwise be necessary. It also allowed me to maintain the complexity of my study that is inherent to research grounded in multiracial feminism.

\section{Definitions and Categorization of Participants}

Elsewhere in the literature, feminists have discussed the importance of understanding definitions prior to conducting research (Acker, 1999). Before recruiting my sample, I also needed to define the categories of women included in the study. These categories consisted of lesbians in general, lesbian mothers and childfree lesbians more specifically, and lesbians of diverse race and class backgrounds. As I developed and operationalized definitions, I faced several challenges.

It is not easy to define who falls into the category of lesbian. Although the common understanding of lesbians are women who have intimate and sexual relationships exclusively with other women, researchers have found that the sexual experiences of lesbians vary considerably. For example, Rust (1992) found that women who identified as lesbians had many similar sexual experiences as women who identified as bisexual. In an attempt to respect the 
identities of women, and in keeping with past research on lesbians, I defined lesbians as women who identify themselves as lesbian (Weston, 1991).

For the purpose of this study, lesbian mothers were defined as lesbians who, within their identities as lesbians, had become or were actively seeking to become mothers (i.e., in the process of adopting or inseminating). I excluded from the study women whom I refer to as the "first generation" of lesbian mothers (i.e., women who had birthed or adopted children while in heterosexual relationships and later identified as lesbians). I excluded these women based on my assumption that-because they made their mothering decisions within heterosexual relationships - their decisions may have involved different factors (e.g., easy access to sperm that could lead to accidental pregnancies, the pressures of seemingly-heterosexual women to have children) than those women who openly identified as lesbian when they become mothers, referred to as the "second generation" of lesbian mothers. Because understanding how sexuality shapes the decision-making process was a fundamental component of my study, including women who made mothering decisions within their identities as lesbian was critical to the study, despite the effect it had on reducing the pool of potential participants from which I could draw.

Childfree lesbians were defined as lesbians who did not desire to enter into motherhood within their lifetimes and who did not already have children (Bartlett, 1994). I chose the term "childfree" because it does not center "mother" as the norm (as does "nonmother" or "not-mother") and does not suggest a lack of something (as does "childless"). To me "childfree" suggested a positive state where women are free from the responsibilities of child raising (Bartlett, 1994). During my focus groups with childfree women, I asked about this terminology. The responses I received suggest that childfree is as problematic as other terms because many "childfree" lesbians have children firmly situated in their lives and do not consider themselves free from the responsibilities of child care. Some participants agreed with the term; others had never heard of it prior to the interview. Amy, a participant in the childfree middle-class lesbian of color group said that "lucky" might be a better term because she considered herself lucky to be able to choose to not have children. Roxanne, another participant in that same group stated, "There's a phrase that I choose to use. It's not just one single word... It's not being childfree; it's [that] I'm not dropping the mother load." Although I appreciate both the humor and seriousness with which Amy called herself lucky, that term does not represent the sentiments and experiences of other women in the study. Similarly, I love the imagery of Roxanne's phrase. However, using it would create many long-winded sentences. Thus, lacking any better language, I chose to use "childfree" throughout the study.

Michigan Family Review, 10, 45-65, 2005 C Michigan Council on Family Relations 
As with the term lesbian, potential participants defined their own racial identities (Luttrell, 2000). Because of difficulties in the recruitment of African American and Latina lesbians, I collapsed racial categories into lesbians of color and White lesbians. "Lesbians of color" refers to lesbians who identified as African American and/or Latina. "White lesbians" are those who identified as White.

Although class can be divided into several different categories, I focused on middle-class and working-class lesbians, grouped loosely on two initial criteria: education and occupation. Although definitions of class also often include income and wealth (Eitzen \& Baca Zinn, 2004), I did not try to ascertain either of those at the time of recruitment for fear of offending potential participants. I determined education and occupation by asking each potential participant to fill out a brief recruitment questionnaire (see Appendix). I classified working-class participants as those with an associate degree or less and who worked at "blue collar" jobs. Middle-class participants had a bachelor's degree or higher and worked at managerial or professional jobs. In cases where education and occupation did not neatly fit into either category, I used any additional information I had about the participant, such as their partner's occupation, to help determine their class position. Because I knew some of the participants through lesbian networks, I often had some additional background information. In cases where I did not have any additional information, I would ask the participant directly for information about their partners and their family backgrounds that might help me determine class position.

Despite my efforts, class remained a difficult category to define. In my effort to not offend potential participants, and in not anticipating discrepancies between my own definitions of class and participants' self-identities concerning class, the definition of class I used created serious challenges during the interviewing process and analysis. The implications of the complexity of defining and operationalizing class are that researchers need to pay close attention throughout the research process to their own definitions and to how participants self-identify. Although there are greater initial difficulties in using a complex definition of class, ultimately such definitions are likely to yield a more rewarding and accurate analysis than research projects relying on simplified definitions.

Even though I was unable to address definitional challenges during the recruitment and interviewing processes, I addressed these challenges during my analysis by including the participant's self-identification of class, as well as my own assessment based on education, income, and occupation, to determine each participant's class position. The adjustments I made throughout the study 
showed some clear socio-economic distinctions among the participants that ultimately made it possible for me to analyze the data by class. Starting with one definition of class, but being flexible in modifying it as the research unfolded worked well in this study and is part of a reflexive, feminist research methodology (Thompson, 1992).

\section{Insider/Outsider Status}

A major aspect of feminist research is to acknowledge and question one's own place in the research process (Allen, 2004; Baber, 2004; Grossman, Kruger, \& Moore, 1999). According to Rosaldo (1993), every researcher is a positioned subject in that $\mathrm{s} / \mathrm{he}$ "occupies a position or structural location and observes with a particular angle of vision" (Rosaldo, 1993, p. 19). Thus, a third consideration I had in recruiting a diverse sample was trying to determine where I fit into the research as a positioned intellectual, that is, as both an insider and outsider. Understanding myself as a positioned intellectual allowed me to understand why recruiting at times was easy and at other times extremely frustrating.

According to Ohnuki-Tierney (1984) and Lewin (1995), positioned intellectuals (or what Ohnuki-Tierney refers to as "native anthropologists") are scholars who study their own cultures. Positioned intellectuals may find themselves in the curious position of being "native" (i.e., an insider) to part of their culture, but "foreign" (i.e., an outsider) to other parts. For example, lesbian ethnographers have found that lesbian participants do not necessarily consider the researcher to be part of their community, "at least not in the sense that [their] identities and experiences share some centrally defining sameness" (Lewin, 1995, p. 326). Thus researchers must reposition themselves as they engage in different circumstances and settings of their research.

The result of being a positioned intellectual is that I experienced being both an insider and outsider. Like other researchers (Andersen, 1993; Baca Zinn, 1979; Gold, 1997; Kennedy \& Davis, 1993; Weston, 1991), I too found that having insider/outsider status has advantages and disadvantages. Having some groups of lesbians perceive me as an insider helped me gain access to those groups. But having some groups perceive me as an outsider made them wary of talking with me and participating in my study. Although I tried to present myself as an insider to all groups of lesbians, my race and class position often prevented me from being successful in the recruitment process. For example, although I was a lesbian within the larger lesbian "community," as a White, middle-class lesbian mother researching lesbians of color, working-class lesbians, and childfree lesbians, my insider status weakened considerably. In recruiting White 
lesbians (of any class or motherhood status) I was an insider. I knew many of the potential participants or at least traveled in similar social circles. Even gaining access to groups of White lesbians that I did not know (for example in bars, at church services, or at meetings) involved a comfortable rapport between me and the potential participants. However, I was very much an outsider among many groups of lesbians of color. Often I could not gain access to lesbian of color events. During the few times I did gain access, I felt that the lesbians in the group were keeping their distance from me, being very wary of my status as a White lesbian and as a researcher. The result of my insider/outsider status in recruiting was an abundance of White middle-class lesbians and a difficulty in recruiting lesbians of color and working-class lesbians.

\section{Issues of Power and Control}

Because of the difficulty I had in recruiting lesbians of color and working-class lesbians, it occurred to me what little control I had over the recruitment process. Both feminist and nonfeminist researchers have reflected upon the unequal power structures within researcher-participant relationships. Researchers have argued that there is an unequal relationship because the researcher maintains a certain power over the participant, particularly regarding the exploitation of research participants by researchers and authorship of the final product (Baca Zinn, 1979; Buroway, 1991; Gorelick, 1991; Stacey, 1988; Thompson, 1992).

Although I agree with the ethical issues concerning unequal power relations that these scholars raise, during the recruitment process I felt as if potential participants had more power over me than I had over them. That is, in needing to recruit a diverse sample, potential participants had the ability to refuse to participate, thus leaving me without a study. Often I found this lack of control frustrating, causing me to reflect upon the possible devastating effects this could have on my research project. My reflection led me to an understanding of how fluid power relations within research can be. During the recruitment process I might have had power to define terms and thus include or exclude certain groups of lesbians (e.g., lesbians who had children within heterosexual relationships/identities). However, lesbians had similar power over me in that they could choose not to participate in my study. Throughout the recruitment process, I was very aware of my lack of power over potential participants. In fact, feeling like I was hustling, pestering, and at times nearly begging people to participate was a constant reminder that I was at the mercy of the goodwill of those who might be willing to participate. And the more of an outsider I was to any given group of potential participants, the more powerless I felt. 
Although frustrated by my lack of power in the recruitment process, the fluid power relations I experienced was a refreshing reminder of the complexities of power relations in general. Part of the multiracial feminist project is to recognize, analyze, and attend to unequal power relations. In fact, a distinguishing feature of multiracial feminism is the centrality of power as a relational structure that creates situations in which the same person at one moment dominates and at another moment is dominated (Baca Zinn \& Dill, 1996). I saw the shifting power relationships as a healthy part of research because it made me mindful of the needs lesbians have in determining at what point they are willing to share their lives with, and at what point they want to protect themselves from, outsiders. In addition, participants' power over me in the recruitment process ensured that $I$ be respectful of them in recruiting them for, and retaining them during, the study.

\section{Sampling Strategies}

The final consideration and challenge I faced was to determine sampling strategies in order to find potential participants and convince them to participate in the study. Prior to going into the field, I selected the geographic parameters for recruitment that were feasible for me to access. I chose five counties because I was familiar with and had contacts in those areas, they offered access to a large population of lesbians from which to draw a diversified sample, and they were within close proximity to my home base and to one another.

After selecting my geographic area, I needed to identify participants and recruit my sample for the focus groups. To do this, I used a combination of snowball and purposive sampling. Snowball sampling is particularly useful when identifying hidden populations (Rea \& Parker, 1992) such as lesbians. Purposive sampling allowed me to recruit each specific category of lesbians based on race, class, and mothering decision (i.e., if a mother or childfree). Snowball sampling proved to be the most effective method of recruitment for all groups of lesbians and therefore helped me overcome one of the major challenges of finding participants. Initially, snowball sampling helped recruit White middleclass lesbians. As a member of a lesbian mothers' support group and as an active member in the lesbian community, I had access to many White middle-class lesbians, some middle-class lesbians of color, and some White working-class lesbians who fit the criteria for the study. The lesbians I knew in the community helped me make contacts with other lesbians in the area.

In addition to snowball sampling, and to recruit lesbians outside my social networks (particularly lesbians of color and working-class lesbians), I used five sampling strategies. First I advertised the study and criteria for participants 
in a lesbian publication that reaches over 2,000 lesbians throughout the state. Second, I recruited potential participants from lesbian social locales such as feminist bookstores, coffee houses, and bars in the targeted counties. Third, I visited lesbian organizations and religious groups in the five counties. Fourth, I advertised at community colleges, four-year colleges, and universities. Finally, I advertised on local online listservs that targeted lesbians of diverse backgrounds. Upon making initial contacts, I continued to use snowball sampling to expand the sample. Using a combination of sampling strategies, I was able to recruit a fairly diverse sample.

\begin{tabular}{|c|c|c|c|c|c|c|c|}
\hline & $\begin{array}{l}\text { Snowball } \\
\text { Sampling }\end{array}$ & $\begin{array}{c}\text { Lesbian } \\
\text { Publica- } \\
\text { tions }\end{array}$ & $\begin{array}{l}\text { Lesbian- } \\
\text { of-Color } \\
\text { Listserv }\end{array}$ & $\begin{array}{c}\text { Local } \\
\text { Lesbian } \\
\text { Mothers' } \\
\text { Group }\end{array}$ & $\begin{array}{l}\text { Flyer in } \\
\text { Bookstore }\end{array}$ & $\begin{array}{c}\text { Lesbian } \\
\text { Bars }\end{array}$ & $\begin{array}{c}\text { Church or } \\
\text { Religious } \\
\text { Group }\end{array}$ \\
\hline $\begin{array}{l}\text { Lesbian-of-Color } \\
\text { Middle-class } \\
\text { Moms }\end{array}$ & 2 & & & 2 & & & \\
\hline $\begin{array}{l}\text { Lesbian-of-Color } \\
\text { Middle-class } \\
\text { Childfree }\end{array}$ & 3 & 1 & & & & & \\
\hline $\begin{array}{l}\text { Lesbian-of Color } \\
\text { Working-class } \\
\text { Moms }\end{array}$ & 2 & & 1 & & & & \\
\hline $\begin{array}{l}\text { Lesbian-of-Color } \\
\text { Working-class } \\
\text { Childfree }\end{array}$ & 1 & & & & & & 1 \\
\hline $\begin{array}{l}\text { White } \\
\text { Middle-class } \\
\text { Moms }\end{array}$ & 1 & & & 5 & 1 & & \\
\hline $\begin{array}{l}\text { White Middle- } \\
\text { class Childfree }\end{array}$ & 4 & 1 & & & & & 2 \\
\hline $\begin{array}{l}\text { White Working- } \\
\text { class Moms }\end{array}$ & 1 & & & 2 & & & \\
\hline $\begin{array}{l}\text { White Working- } \\
\text { class Childfree }\end{array}$ & 2 & & & & & 3 & \\
\hline Totals & $\begin{array}{c}16 \\
(45.7 \%)\end{array}$ & $\begin{array}{c}2 \\
(5.7 \%)\end{array}$ & $\begin{array}{c}1 \\
(2.9 \%)\end{array}$ & $\begin{array}{c}9 \\
(25.7 \%)\end{array}$ & $\begin{array}{c}1 \\
(2.9 \%)\end{array}$ & $\begin{array}{c}3 \\
(8.6 \%)\end{array}$ & $\begin{array}{c}3 \\
(8.6 \%)\end{array}$ \\
\hline
\end{tabular}

Table 1 gives a breakdown of how I recruited participants in the study. I recruited nearly half $(45.7 \%)$ of the sample through snowball sampling. I recruited one quarter of the sample from two local lesbian mother groups. Close to 20 percent of the sample was recruited from religious groups or lesbian bars. I 
recruited the remaining 12 percent of the sample from listservs and advertisements/flyers. Twenty-nine $(82.9 \%)$ of the participants came from my local area, four $(11.4 \%)$ came from a larger city, and two $(5.7 \%)$ came from different smaller cities in the state.

Despite my efforts, I found recruiting lesbians of color and working-class lesbian mothers (of any racial background) very difficult. I had hoped to recruit working-class lesbians from a particular county known for its large working-class population. However, despite several contacts I made at colleges, local organizations, and work places, I was unable to recruit even one lesbian from that county. I was informed by several sources that lesbians in that area are particularly closeted and reluctant to participate in studies, lest the study reveal their identities and they be faced with dire social and economic ramifications.

My inability to recruit working-class lesbians from that county was mirrored in other geographic areas. Through all my recruiting efforts, I was unable to recruit many working-class mothers of any racial backgrounds. It is possible that if given more time and resources, I might have been able to recruit more working-class lesbian mothers. However, I suggest that my difficulty in recruiting working-class lesbian mothers was not only because of their fear of having their sexual identities exposed but also because there may be a limited number of working-class lesbian mothers, as I defined them for this study. Because donor insemination and adoption can be costly, because working-class positions in the labor force offer less flexible schedules and fewer health benefits than middle-class positions, and because working-class women need to work long hours to earn a living wage, it is possible that working-class lesbians are unable to afford children and therefore do not see motherhood as a real option.

In addition, because of the HIV/AIDS epidemic, lesbians are not likely to choose the less expensive option of using known donors (Bernstein \& Stephenson, 1995; Stacey, 1996; Weston, 1991). Furthermore, I found that because working-class lesbians are not as well integrated into important social networks of lesbian mothers as are middle-class lesbians, they are less likely than their middle-class counterparts to have access to knowledge about how to become mothers. Therefore, the complex relationship between work, leisure time, income, health insurance, and access to sperm and reproductive technologies, makes motherhood less of a choice for working-class lesbians than for middle-class lesbians.

In addition to the problems of recruiting working-class lesbians, I found that African American lesbian communities in large cities remained closed to my recruiting efforts. I made numerous unsuccessful trips to recruit lesbians of color 
from the largest city in the study area. As I continued my recruiting efforts, I learned two main reasons why African American lesbians lacked an interest in my study. First, many of the lesbians with whom I met were first-generation lesbian mothers and therefore did not meet a major criterion for participation. Often these women were leaders in their communities. Because they seemed frustrated by my narrow definition of lesbian mother, it is possible that they discouraged others from participating in the study.

As stated earlier, my intention of using a narrow definition of lesbian mother was to maintain the integrity of the sample. Although I did not want to offend or frustrate any women, I remained committed to my definition of lesbian mother throughout the study. Second, because African American lesbians have experienced discrimination from White lesbians, there is a large racial division in that city's lesbian "community." Several African American lesbians from support groups informed me that I was not welcome to recruit during their sessions because these events were exclusively for lesbians of color. However, the group leaders told me I could come afterward to recruit. The three times I showed up to recruit at the end of such groups, I discovered upon arrival that the meetings had been cancelled. My experience recruiting African American lesbians led me to two possible conclusions: African American lesbian groups are poorly attended and/or are purposefully hidden from Whites.

As with other steps in the methodological process of my study, the difficulty I had in recruiting lesbians from diverse race and class backgrounds forced me to be flexible. Prior to conducting the research, I had decided not to include intimate partners in the same focus group. If participants had partners who were willing to participate in the study, I originally decided to include the partner in a separate focus group. However, because I had so few lesbians of color and working-class lesbians, when couples showed up unannounced to the focus groups (which happened on two occasions), I let them remain together.

Because there is a dearth of literature discussing the consequences of couples showing up uninvited to focus groups, I can only surmise that the fact that couples showed up together to my study may be the "hazard" of doing research involving same-sex couples. A researcher would be less likely, for example, to have the uninvited spouse of a heterosexual couple show up to a focus group where only husband or wives were being interviewed. It would be equally unlikely that the researcher would allow the uninvited spouse to stay and participate. Despite this hazard, my experience was that interviewing partners had no negative impact on the study. In fact, because it increased the number of participants, and the participants did not appear to restrict their responses due to the presence of their partners, having both partners present proved to be a

Michigan Family Review, 10, 45-65, 2005 C Michigan Council on Family Relations 
positive experience in my study. Table 2 shows the end result of my recruiting efforts.

\begin{tabular}{lllllc}
\hline \multicolumn{5}{c}{ Table 2. Distribution of Participants in Focus Groups } \\
\hline \multicolumn{5}{c}{ Lesbian Mothers } & \multicolumn{2}{c}{ Childfree Lesbians } \\
\hline & Working-class & Middle-class & Working-class & Middle-class & Totals \\
& $3^{*}(8.6 \%)$ & $4(11.4 \%)$ & $2(5.7 \%)$ & $4(11.4 \%)$ & $13(37.1 \%)$ \\
Lesbians of color & $3(8.6 \%)$ & $7(20.0 \%)$ & $5(14.3 \%)$ & $7(20.0 \%)$ & $22(62.9 \%)$ \\
White Lesbians & & & & & \\
Totals & $6(17.2 \%)$ & $11(31.4 \%)$ & $7(20.0 \%)$ & $11(31.4 \%)$ & $35(100 \%)$ \\
\hline
\end{tabular}

* conducted in two separate interviews

In my study, there was almost an even division between lesbian mothers (17) and childfree lesbians (18). Participants fell between the ages of 22 and 46 years, a range that minimizes a cohort effect. Thirteen $(37.1 \%)$ of the participants were either African American or Latina. The remaining 22 (62.9\%) were White. Similarly, 13 (37.1\%) women participated in working-class focus groups, while $22(62.9 \%)$ women participated in middle-class focus groups. However, as discussed earlier, several of the participants in the middle-class focus group identified themselves as working-class and came from working-class backgrounds. Therefore, the breakdown of participants by class in Table 2 is not neatly discernable.

Despite my inability to recruit an equal number of lesbians of color and White lesbians, or as many working-class lesbians as I had hoped, the racial stratification of my study loosely reflects that of the U.S. population. As shown in Table 3, the percent of White participants in the focus groups closely resembles the percent of Whites in the U.S. Furthermore, my sample overrepresents African Americans compared to the U.S. population. Although comparing U.S. demographics to those of my participants is problematic because the U.S. demographics include men and people outside the age groups of my study, Table 3 gives a general picture that my sample is at least as stratified as the U.S. population. Therefore, although I did not recruit the sample I had hoped for, I did recruit a loosely representative sample of the U.S. population.

\begin{tabular}{lcc}
\hline Table 3. & Race Stratification in Focus Groups and U.S. Population \\
\hline & Focus Groups & U.S. Population (2000) \\
\hline African American & $25.7 \%$ & $12.3 \%$ \\
Latino & $11.4 \%$ & $12.5 \%$ \\
White & $62.9 \%$ & $69.1 \%$ \\
& & $93.1 \%$ \\
\hline
\end{tabular}




\section{Discussion: How Multiracial Feminist Research Benefits Family Scholarship}

In designing my study and recruiting participants, I found that multiracial feminist research centering race, class, gender, and sexuality is complicated and often frustrating. If researchers are committed to using a feminist methodology based on multiracial feminism, they must be prepared to develop complex research designs and innovative sampling strategies. Two main points are important to stress in discussing the complexities and frustrations of conducting this research.

First, the frustration and difficulties of conducting multiracial feminism lie in the very categories that inform the methodology of the study. By committing to research guided by multiracial feminism, one has to carefully attend to the methodology. It is this careful attention to method that is simultaneously critical to the study and the very aspect of the research that creates snags, frustrations, and cause for reflection during the research process. There were many times during the early stages of my research and the recruitment process that I seriously considered simplifying the study by focusing on just lesbian mothers, or just childfree lesbians, or just one racial or class group. However, I always came back to the same conclusion: While allowing me to finish the study more quickly, simplifying meant compromising the very heart and soul of the study. And so by choosing a comprehensive theoretical grounding, I was choosing to conduct a comprehensive, and inherently complex, study.

The complexity of the study not only lies in the fact that multiracial feminism demands a comprehensive methodology but also in the fact that the various steps of the research process are connected. It is critical, therefore, that the researcher reflects upon each step and makes careful decisions all the way through the research project. In my study, the lines between individual steps became blurred. The method I chose was not only connected to the research questions I was asking but also to how I defined categories of participants and the social location of those participants. The social location of the participants forced me to reflect upon my own position within the project—as well as on the power relations created during the recruitment process-because of our various social locations. I also found that the definitions I chose affected who I could recruit and who I was purposefully excluding - which ultimately affected how many people I could recruit. Thus, the definitions I chose, as well as my own position as insider and/or outsider, greatly affected the final composition and number of participants. My own research experience leads me to conclude that to effectively 
conduct multiracial feminist research, one must not only pay attention to individual methodological steps, but also to the connections between those steps.

Second, despite the difficulties and frustrations inherent in conducing multiracial feminist research, the rich data such a study produces is worth the effort involved. By recruiting a diverse sample I was able to reveal aspects of lesbians' mothering decisions that to date have been invisible within the growing body of literature on lesbian families. For example, in studying childfree lesbians, I found that racial discrimination leads some lesbians of color, particularly African American lesbians, away from motherhood. Perhaps the most disturbing finding of the study was that African American lesbians from the middle-class childfree group remain childfree partly because they cannot see raising children, particularly female children, in a racist, sexist, and heterosexist world. Racial discrimination from the outside world, coupled with homophobia within communities of color, led some lesbians to be oriented away from motherhood at early ages. This finding illustrates how structures of race can fundamentally change the decision-making process.

Similarly, I found that lesbians' experiences with structures of sexuality in the form of sexual discrimination often steers lesbians toward remaining childfree. Heterosexist family policies and homophobic ideology led some lesbians to dismiss motherhood because they believe it is unfair to raise children in a homophobic and heterosexist world. In addition, structures of sexuality shaped decision-making processes differently for lesbians than for heterosexual women because lesbians do not receive the same medical and legal support as heterosexual women. The denial of same-sex adoption, domestic partner benefits, and medical assistance to lesbians led some lesbians in my study to remain childfree. As several participants stated, the effort it takes to have a child given the heterosexist bias in legal and medical institutions, steers many lesbians onto childfree paths.

In the midst of these structural constraints, many lesbians make intentional decisions to remain childfree. In the face of the lesbian baby boom, many childfree lesbians feel strongly that they maintain the benefits of personal and economic freedom. Most childfree lesbians in the study were comfortable with and proud of their mothering decisions. One reason for the high comfort level was because many childfree lesbians have found a balance between personal freedom and connections with children. Very few childfree lesbians in my study regretted their mothering decisions. In fact, many stated that heterosexual women can learn from lesbians that motherhood is a choice, not a natural path for all women. Heterosexual women can also learn that there are many fulfilling identities and goals that women can have outside of motherhood.

Michigan Family Review, 10, 45-65, 2005 C Michigan Council on Family Relations 
Just as childfree lesbians renegotiate their definitions of what it means to be a woman, lesbian mothers renegotiate their definitions of what it means to be a mother. I found that many White middle-class lesbians were oriented toward remaining childfree as girls because they interpret motherhood as oppressive to women. However, in adult life many developed positive views of lesbian motherhood, particularly as they experienced egalitarian lesbian relationships. That is, while they see heterosexual motherhood as oppressive to women, their ideas about and experiences with egalitarian lesbian relationships allowed them to move comfortably into lesbian motherhood.

These examples illustrate how incorporating a study grounded in multiracial feminism and requiring a research methodology centered around difference allows researchers to discover rich findings that otherwise remain hidden. By recruiting a diverse sample, I was able to begin to understand how race, class, gender, and sexuality shape lesbians' decisions to become mothers or remain childfree. Although we have learned much from studies that do not center difference, without looking at the diversities within lesbian families, we not only further marginalize lesbians of color and working-class lesbians by making their families invisible but we also produce incomplete information about lesbian families. The strength of a feminist methodology is that it brings us to a deeper understanding of women's lives (Thompson, 1992). The strength of a multiracial feminist methodology is that it brings us to a deeper understanding of a diverse group of women's lives. When applied to family studies, the strength of a multiracial feminist methodology is that it allows researchers to produce knowledge about families that otherwise remains obscured by researchers' inability to see beyond White, middle-class experiences. And this strength is worth all the complexities and frustrations inherent in designing and conducting multiracial feminist research. 


\section{References}

Acker, J. (1999). Rewriting class, race, and gender: Problems in feminist rethinking. In J. Lorber, B. Hess \& M. M. Ferree (Eds.), Revisioning gender (pp. 44-69). Thousand Oaks, CA: Sage.

Allen, K. R. (2004). Janet Saltzman Chafetz plenary: Discussant comments. Journal of Family Issues, 25(7), 984-989.

Andersen, M. L. (1993). Studying across difference: Race, class, and gender in qualitative research. In J. H. Stanfield, II \& R. M. Dennis (Eds.), Race and ethnicity in research methods (pp. 39-52). Newbury Park, CA: Sage.

Baber, K. M. (2004). Building bridges: Feminist research, theory, and practice. Journal of Family Issues, 25(7), 978-983.

Baca Zinn, M. (1979). Field research in minority communities: Ethical, methodological, and political observations by an insider. Social Problems 27(2), 209-219.

Baca Zinn, M., \& Dill, B. T. (1996). Theorizing difference from multiracial feminism. Feminist Studies, 22(2), 321-331.

Bartlett, J. (1994). Will you be mother? Women who choose to say no. London: Virago Press.

Bernstein, J., \& Stephenson, L. (1995). Dykes, donors \& dry ice: Alternative insemination. In K. Arnup (Ed.), Lesbian parenting: Living with pride \& prejudice (pp. 3-15). Charlottetown, Canada: gynery books.

Black, D., Gates, G., Sanders, S., \& Taylor, L. (2000). Demographics of the gay and lesbian population in the United States: Evidence from available systematic data sources. Demography, 37(2), 139-154.

Burawoy, M. (Ed.). (1991). Ethnography unbound: Power and resistance in the modern metropolis. Berkeley, CA: University of California Press.

Chafetz, J. S. (2004). Bridging feminist theory and research methodology. Journal of Family Issues, 25(7), 963-977.

Deem, R. (2002). Talking to manager-academics: Methodological dilemmas and feminist research strategies. Sociology, 36(4), 835-855.

Demo, D. H., \& Allen, K. R. (1996). Diversity within lesbian and gay families: Challenges and implications for family theory and research. Journal of Social and Personal Relationships, 13(3), 415-434.

Michigan Family Review, 10, 45-65, 2005 C Michigan Council on Family Relations 
Eitzen, D. S., \& Zinn, M. B. (2004). In conflict and order: Understanding society (10th ed.). Boston: Allyn \& Bacon.

Gold, S. (1997). A White guy among Vietnamese women. In M. B. Zinn, P. HondagneuSotelo \& M. A. Messner (Eds.), Through the prism of difference: Readings onsSex and gender. Boston: Allyn \& Bacon.

Golombok, S., \& Tasker, F. (1997). Children in lesbian and gay families: Theories and evidence, in Lesbians raising sons (pp. 158-187). New York: Alyson Books.

Gorelick, S. (1991). Contradictions of feminist methodology. Gender \& Society, 5(4), 459-477.

Grossman, F. K., Kruger, L. M., \& Moore, R. P. (1999). Reflections on a feminist research project: Subjectivity and the wish for intimacy and equality. Psychology of Women Quarterly, 23, 117-135.

Harding, S. (1991). Whose science? Whose knowledge? Ithaca, NY: Cornell University Press.

hooks, b. (1989). Talking back: Thinking feminist, thinking Black. Boston: South End Press.

Jarrett, R. L. (1993). Focus group interviewing with low-income minority populations: A research experience. In D. L. Morgan (Ed.), Successful focus groups: Advancing the state of the art (pp. 184-201). Newbury Park, CA: Sage.

Kennedy, E. L., \& Davis, M. D. (1993). Boots of leather, slippers of gold: The history of a lesbian community. New York: Routledge.

Knodel, J. (1993). The design and analysis of focus group studies: A practical approach. In D. L. Morgan (Ed.), Successful focus groups: Advancing the state of the art (pp. 35-64). Newbury Park, CA: Sage.

Lewin, E. (1993). Lesbian mothers: Accounts of gender in American culture. Ithaca, NY: Cornell University Press.

Lewin, E. (1995). Writing lesbian ethnography. In R. Behar \& D. A. Gordon (Eds.), Women writing culture (pp. 322-335). Berkeley, CA: University of California Press.

Luttrell, W. (2000). "Good enough" methods for ethnographic research. Harvard Educational Review, 70(4), 499-515.

Mooney-Somers, J., \& Golombok, S. (2000). Children of lesbian mothers: From the 1970s to the new millennium. Sexual and Relationship Therapy, May, 121-126.

Michigan Family Review, 10, 45-65, 2005 C Michigan Council on Family Relations 
Morgan, D. L. (1997). Focus groups as qualitative research. Thousand Oaks, CA: Sage.

Morgan, D. L., \& Krueger, R. A. (1993). When to use focus groups and why. In D. L. Morgan (Ed.), Successful focus groups: Advancing the state of the art (pp. 3-19). Newbury Park, CA: Sage.

Morningstar, B. (1999). Lesbian parents: Understanding developmental pathways. In J. Laird (Ed.), Lesbians and lesbian families: Reflections on theory and practice (pp. 213-241). New York: Columbia University Press.

O’Sullivan, S. (1995). Dykes and diapers: Why children? Deneuve Magazine, 5(5), 16.

Ohnuki-Tierney, E. (1984). 'Native' anthropologists. American Ethnologist, 11(3), 584585.

Rea, L. M., \& Parker, R. A. (1992). Designing and conducting survey research: A comprehensive guide. San Francisco: Jossey-Bass.

Riessman, C. K. (1991). When gender is not enough. In J. Lorber \& S. A. Farrell (Eds.), The social construction of gender (pp. 217-236). Newbury Park, CA: Sage.

Rosaldo, R. (1993). Culture \& truth: The remaking of social analysis. Boston, MA: Beacon Press.

Rust, P. C. (1992). The politics of sexual identity: Sexual attraction and behavior among lesbian and bisexual women. Social Problems, 39(4), 366-386.

Stacey, J. (1988). Can there be a feminist ethnography? Women's Studies International Forum, 11(1), 21-27.

Stacey, J. (1996). In the name of the family: Rethinking family values in the postmodern age. Boston: Beacon Press.

Stacey, J., \& Biblarz, T. J. (2001). (How) does the sexual orientation of parents matter? American Sociological Review, 66, 159-183.

Thompson, L. (1992). Feminist methodology for family studies. Journal of Marriage and the Family, 54, 3-18.

Weston, K. (1991). Families we choose: Lesbians, gays, kinship. New York: Columbia University Press.

Michigan Family Review, 10, 45-65, 2005 C Michigan Council on Family Relations 


\section{Appendix: Recruitment Questionnaire}

If you are willing to participate in a group interview for my study on lesbians' decisions to remain childfree or to mother, please answer the following questions:

Name:

Age:

Telephone \# and/or email address:

City/Town of Residence:

Are you employed? Yes No

If you are employed, what is your occupation/job?

What is your highest level of education (High school, GED, Associates Degree, $\mathrm{BA}, \mathrm{MA}$, etc.)

What is your racial background (African American, Latina, White/ Caucasian, etc.)

Do you have any children, are you or your partner pregnant, or are you or your partner in the process of adopting a child?

Yes (please explain)

No

If you have children, are they from a previous heterosexual relationship or did you have/adopt them as a lesbian?

If you do not have any children, do you plan on having children in the future?

What days/times are you available to participate in a 2-3 hour group interview? (e.g., evenings, weekends) 